\title{
The Language of Urban Development in Johannesburg's Inner Gity
}

\author{
Gilles Baro \\ Department of Linguistics, School of Literature, Language \\ and Media at the University of the Witwatersrand
}

Correspondence to: gilles.baro@gmail.com

\begin{abstract}
This article engages with the language used by urban developers when planning areas of a city and how it influences the way media and social actors come to represent place. Its theoretical approach proposes a language of urban development based on Markus and Cameron's (2002) language of buildings concept, which looks at the discourse used by architects and promoters in the construction of buildings. An analysis of interviews with developers and social actors of the inner city of Johannesburg as well as media articles portraying the area shows a correlation between the discourse used by all three bodies in terms of both the Western aspiration of an urban development model and the importance of safety and cleanliness to signify accessibility of place in Johannesburg.
\end{abstract}

Key words: Johannesburg, post-apartheid, urban development, linguistic landscape studies, representation, regeneration

\section{INTRODUCTION}

Johannesburg became a "hip city" in 2015, at least according to the popular travel site Rough Guides, which placed the South African city at the top of its annual list of destinations to visit for that year. The brief description of Johannesburg by the site on its widely read "Top City" list for $2015^{1}$ gives clues as to why the city was not added to the list prior to 2015 . Indeed, the first information given about Johannesburg is that it has a reputation problem, hinting at the fact that it is usually associated with crime and grime as pointed out in the longer description of the inner city on the page dedicated to Johannesburg itself². Such terms evoke a discourse of urban decay, which affected

1. https://www.roughguides.com/best-places/2015/top-10-cities/

2. https://www.roughguides.com/destinations/africa/south-africa/gauteng/johannesburg/ 
the image of the city and how potential visitors perceived it since the 1990s (Beavon 2004). However, the site is quick to point out that "clusters" and "parts" of the city have "broken free from the chains of [the city's] troubled past" thanks to investors and development moving back in, and that some of those parts "should be on the to-do list of any firsttime visitor". Through language, Rough Guides paints a picture of Johannesburg that is negative and having an image problem when development has "fled" and "abandoned" the inner city, and a positive picture once new developments have come back in pockets.

In this article, I aim to show how the language used by such media as well as by urban developers when conceptualizing the rebirth of the city helps construct a representation of Johannesburg aimed at making it attractive to visitors. I will focus particularly on one of those "clusters" - the neighbourhood of Marshalltown - in order to investigate if the language used by planners and developers correlates with how the area is represented by the media and social actors. This task will be done by integrating Markus and Cameron's (2002) particular discourse analysis approach, which aims at marrying architecture and sociolinguistics, an approach so far ignored by the Linguistic Landscape $^{3}$ Studies scholarship, even though it focuses on language and place. They argue that in order to analyse buildings, one must pay attention to the language used by architects and planners when conceptualizing and developing buildings but also the language used to promote and sell them to the public. My aim is to apply their approach to a broader city planning perspective instead of solely an architectural one. Henceforth, the analytical part of the article will focus on a set of data collected during my $\mathrm{PhD}$ research ${ }^{4}$, which includes interviews with urban developers active in the area and media texts about postapartheid development in the inner city.

In what follows, I first present Markus and Cameron's (2002) theoretical framework for buildings and argue for its expansion to the broader field of urban development and planning, as well as its usefulness within linguistic landscape scholarship. I then move on to analyse the language used by developers, social actors and the media with a focus on two particular themes: the role of Western aspirations in the conception and experience of an urban environment and how urban development is seen as a sign of safety by the same bodies. I finally conclude by answering the question: Is there a correlation between how Johannesburg's urban development is discursively constructed by developers, social actors and in media articles?

\section{The language of urban development as place-making}

Markus and Cameron's (2002) main aim is to bring into dialogue two disciplines architecture and (socio)linguistics - which have not typically engaged with one another, and through such engagement offer a new perspective on investigations of the

3. Henceforth LL

4. This article is partly based on my PhD project, which looked at the neighbourhood of Marshalltown in the inner city of Johannesburg with a particular focus, additionally to the one present in this article, on signs of heritage and authenticity. The data from this chapter was collected during a three-year ethnography of the neighbourhood in which I interviewed 12 social actors of Marshalltown and collected 255 photographs of signs as well as 25 media articles from various outlets. 
meanings of buildings. More precisely, they claimed that an examination of the language used to plan, build and represent buildings could "yield insight into the buildings we have now, and the ones we may create in the future" (2002: 2). Markus, an architecture scholar, and Cameron, a sociolinguist, remind us that language is not simply a way to communicate factual information neutrally. As a social practice, rather, language transmits beliefs, opinions and the values of the interlocutors in conversation. Thus, "[t]exts about buildings often turn out to be a source for the social, political and ideological values which other critical techniques reveal by analysing buildings directly" (2002: 4). Markus and Cameron claim that by looking at the language of and about buildings, we not only find factual information about buildings, but also how they are represented, perceived and sometimes politicised, when, for example, they are designed to be exclusionary of certain groups of people or meant to represent a particular ideology.

To take an example from the inner city of Johannesburg, the Anglo American complex located on 44 Main Street served as the headquarters of what was the largest mining corporation in South Africa until its listing on the London Stock Exchange in 1999. The company has kept a base in Johannesburg because of its continuous mining activity in South Africa. One can read the building in terms of its architectural style, and point out such features as its long stained-glass windows and dark sandstone eagles on the front facade, but looking at the language used by Ernest Oppenheimer, who commissioned the building, gives another layer of meaning to the site. Oppenheimer famously proclaimed that he wanted "something between a cathedral and a bank" (Rajak 2011: 3). The comparison to a cathedral explains the long and high stain-glassed windows which give the building a sense of gravitas, suggesting that one should enter it in silence. But it also imbues the company with a sense of 'higher' power.

Markus and Cameron (2002) also point out that buildings are themselves texts (see also Forty 2000), in which elements such as windows, bricks, shapes, décor, and so on, are like components in a sentence, following certain formal rules: windows are selectively placed in order to let light into a room as well as some of the outside air, smell and noise when opened, in much the same way as adjectives are carefully selected in a sentence to have nouns portrayed in a negative or positive way. For Markus and Cameron (2002), the meaning communicated by buildings cannot be directly understood by looking at them. Rather, one has to look at the language surrounding the buildings, how are they are described, conceptualised and commented on:

Buildings, it seems, do not explain themselves. While something like the contrast between light and dark in a Gothic cathedral may be apprehended directly, the significance of that contrast is not apprehended directly. Rather it is apprehended with the assistance of language, in the primary and literal sense of the term. (Markus and Cameron 2002: 8)

For them, reading buildings and conceptualising architecture as a language poses the danger of diminishing the effect played by written and spoken language "in shaping our understanding of the built environment" (2002: 8), and so they argue instead for "an interactive 
relationship between buildings and language rather than [an] analogical one" (2002: 8).

It is important to note that for Markus and Cameron (2002), buildings are material, but the texts about buildings are representational, and these texts are "products of linguistic choices which construct reality in particular ways" (2002: 15-16).

This article focuses not only on certain buildings located in the inner city of Johannesburg, but on the area as a whole. This broad analysis is the reason why I would like to apply Markus and Cameron's main argument on a broader scale: instead of focusing solely on buildings and their architecture, I believe the language of buildings methodology can be turned into a language of urban development. "Indeed, buildings are designed and built by architects using language, but developers from the public and private sectors also use language when planning cities, neighbourhoods, precincts, districts and private enclaves." Each man-made sign in a semiotic and linguistic landscape, from a streetlight to a billboard or rubbish bin, has been discussed by developers as part of an urban development project. The plans of architects, as well as the explanations for new urban spaces on official websites all contain verbal language, and are thus sociolinguistic data that may be investigated in order to understand the representation and use of these spaces.

Following Markus and Cameron (2002), the following sections explore the language used to refer to Johannesburg's inner city and its development. These texts include interviews with developers, planners, shop owners, and users of the area, but also media and academic texts about the inner city as a whole. In this way, I hope to present the broad context of Johannesburg's inner city, while answering the following questions: How is the city represented? What model of urban development in the inner city is talked about by developers? Are social actors able to read the developer's model when experiencing the urban environment? How do the media talk about urban development?

\section{The inner city and its Western aspirations}

It is tempting to think about and read Johannesburg as a city of the global South and analyse it using theories of the South (Comaroff and Comaroff 2012) as brilliantly undertaken by Simone (2008; 2010) and Nuttall and Mbembe (2008). However, Milani (2014) reminds us that "colonies and metropoles were mutually constitutive creating complex forms of social, cultural, economic and epistemological interdependencies" (2014: 8). Indeed, as I have argued elsewhere (Baro forthcoming), Johannesburg was designed and built by Western architects, planners and developers after the discovery of gold in the area with the purpose to host the fastgrowing gold-mining industry (Beavon 2004; Iqani and Baro 2017), and recent redevelopment efforts in its inner city after decades of decaying infrastructure resulting in population and capital flight have echoed Western aspirations of contemporary urban development, notably through the highlighting of the city's heritage, which is in fact a white, European one (Baro forthcoming). The data presented here shows how currently active developers in the inner city of Johannesburg continue to rely on a discourse of Western aspiration when planning and designing the city and how this discourse is experienced by social actors on the streets. 
Urban developers in Johannesburg have looked abroad for inspiration on how to build an attractive urban environment for decades. In order to be considered a "true" metropolis, planners and entrepreneurs in Johannesburg throughout the $20^{\text {th }}$ century hired architects and designers from abroad to give the city a world-class feel. For example, the Barbican building and the Astor Mansions were built respectively in 1930 and 1932 with the intention to "be influenced by the skyscrapers of New York and Chicago" ${ }^{5}$. In 1965, the tallest building was the Schlesinger Building, which was designed as a (smaller) replica of the MetLife building in New York City, but striped in black and white, into an almost diamond-like shape. The multiplications of skyscrapers gave Johannesburg a skyline which could be compared to those of major metropolises abroad.

Furthermore, Nuttall and Mbembe (2008) remind us of the constant aspiration for Johannesburg's architects and city planners to develop the city into a metropolis, based on Western models:

[...] the entire history of Johannesburg's built structures testifies not only to its inscription into the canons of modern Western urban aesthetics, but also to the originary tension virtually built into its morphology and geological structure between the life below the surface, what is above, and the edges. After all, until very recently, Johannesburg described itself as the largest and most modern European city in Africa. As amply demonstrated by Clive Chipkin, this meant that Johannesburg was the progeny of nineteenthcentury European industrial society. This inland city developed as an industrial metropolis supported by gold mining. A breeding ground for modernism, it grew as a frontier city closely tied to the global market economy and the world of consumption and at the same time was mired in bigotry and prejudice, constantly caught between what it could be (potentiality) and what is ended up being (actuality). (2008: 18)

Contemporary developers in Johannesburg's inner city have relied on the concept of the City Improvement District (CID) to control and maintain the environment they aimed to develop. This model entails the property owners in a specified area creating a joint forum with the city that contributes some funds into upgrading the landscape of their district. This might include projects such as pedestrian infrastructure, landscaping, transport hubs, security services, or cleaning services, etc. It allows them to have more control over their environment and their image. One developer, Gerald Olitzki of OPH admits that he and his partners "borrowed the concept from the States" because it "had proven successful in New York" in order to combat urban decay and make the inner city attractive again. For him, Johannesburg was facing a situation similar to the one in New York, where middle-to-upper-class populations were leaving the inner cities for the greener, more spacious suburbs. He acknowledges that the phenomenon of population and capital flight wasn't isolated to Johannesburg, but was particularly significant here:

5. http://www.joburg.org.za/index.php?option $=$ com_content\&task=view\&id=2925\&Itemid=203 
[...] we got to understand, the flight from the inner city is not unique to Johannesburg, you know we've seen it in Paris, it's happened in London, it's happened in New York, it's happened all over the world, but it was so much amplified by the politics of South Africa, that the people just left and fled.

Seeing population and capital coming back into North American and European cities in the late 1990s must have convinced developers such as Gerald Olitzki that Johannesburg was the perfect business opportunity for urban renewal because if it had become popular to move back in these global cities, it might also become popular in Johannesburg.

The desire to live in a metropolis, with its global visual discourse of a specifically Western aesthetic, is evidenced in the interviews I conducted with a young business owner. He tells his story of discovering the wealthy neighbourhood of Marshalltown in the South-West of the inner city, and what it felt like:

I was walking through Joburg for months looking for the perfect spot [to open my store] and I fell in love with Marshalltown. I had never been to New York but I thought Marshalltown represented New York. It gave me the feeling of a working city with the potential to be bigger than what it was. I thought I could contribute into making it the London or New York of Johannesburg. (Andile Cele, owner of DOPE clothing and art shop)

What is striking in Andile Cele's narrative is the feeling of being abroad, in places which he had only seen through films and photographs (New York) or lived in (London). References to the United States, and New York particularly, are often present in the LL of Johannesburg's inner city. For example, a new student accommodation building in Braamfontein is named "The Manhattan"; a billboard on top of the arcade of the newly renovated Stuttafords Building on Rissik Street advertises "NEW YORK STYLE LIVING".

Finally, when entering Cramer's Coffee Shop on Main Street, one can see a large poster with a quote from the David Lynch TV series Twin Peaks, which says "I've just arrived in New York City what a place! Just smell those skyscrapers. Had breakfast at a little cafe on Ninth Avenue. Cinnamon croissant and a cup of coffee, black as a moonless night. Hit the spot." The quote makes a connection between drinking coffee, which one does in a place like Cramer's, and being in this urban environment, highlighted in the quote by the exclamation "what a place!" and the mention of skyscrapers. It is as if

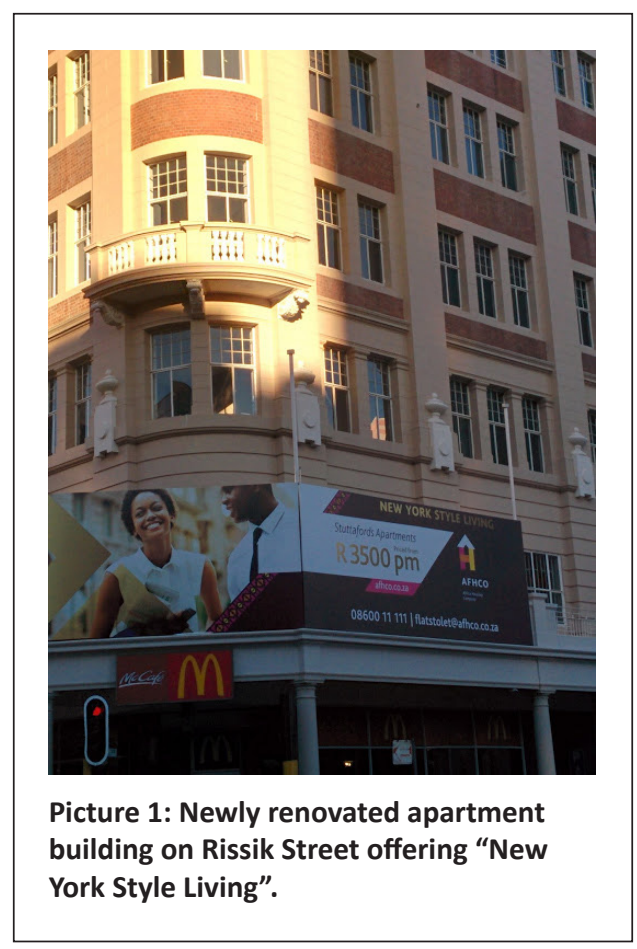




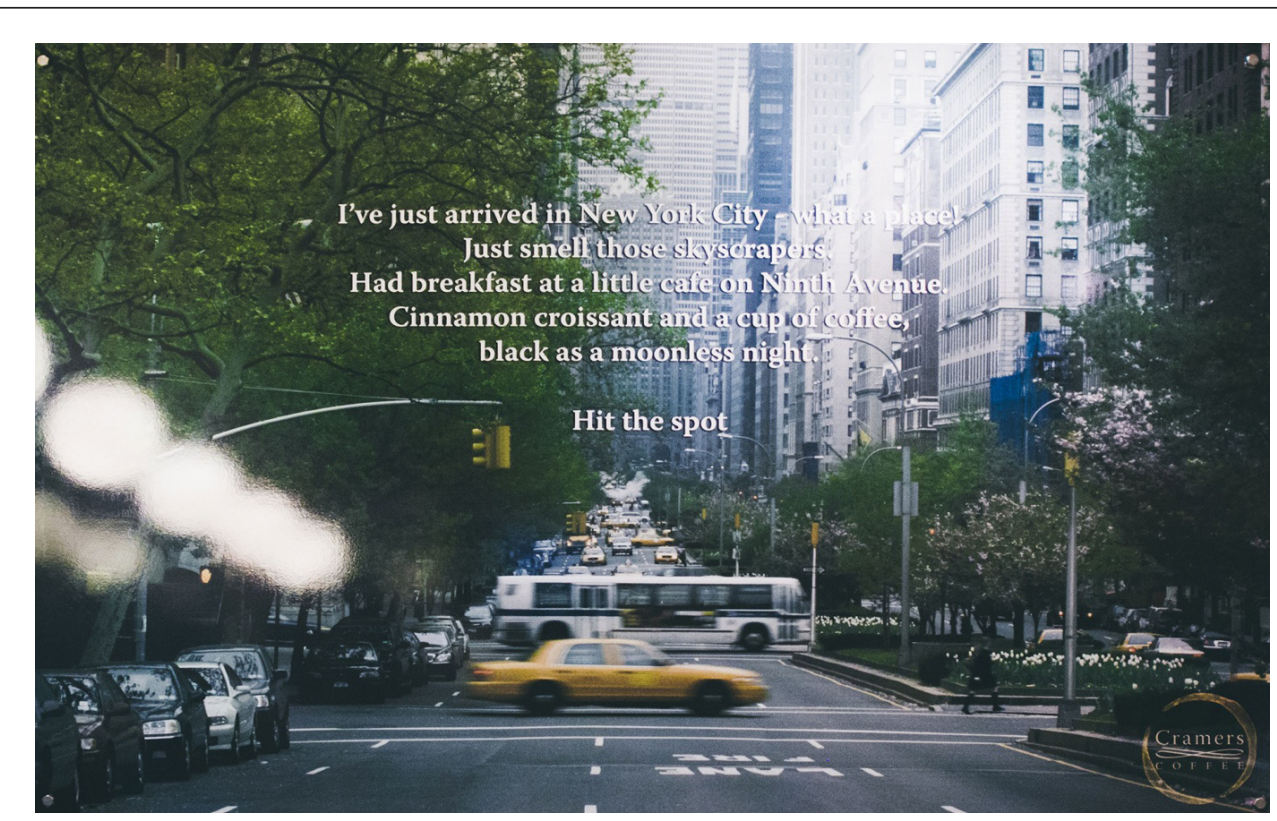

Picture 2: Poster inside Cramers Coffee on Main Street.

the superposition of skyscrapers and a coffee equates to the desired urban experience. Cramer's is located in the heart of Marshalltown, and is thus surrounded by old skyscrapers. The poster is actually multimodal since the quote is placed on top of a photograph of a New York City street.

Another social actor of the inner city of Johannesburg, Hussain van Roos, a former white-collar employee of Standard Bank, also describes his first impression of Marshalltown and compares it to the rest of the inner city:

When the bank called me for an interview, I remember getting lost. I walked from Bree taxi rank because I had no car. When I got to Marshalltown, it felt cleaner. I saw people in suits and ties and I saw fancy cars and I thought, jeez, I'll definitely make it there somehow! So from Bree which is the real downtown, the filthy part of Joburg, and as I walked up I started realizing the buildings were starting to change, I saw old structures and buildings having been kept the way they were back in the days. It felt wonderful to be in a cleaner area. (Hussain van Roos, former Standard Bank employee)

In this narrative, a discourse of cleanliness is employed to describe Marshalltown as well as to differentiate it from the rest of the inner city with terms such as "cleaner" and "fancy" being opposed to "filthy". It is also interesting to note that a discourse of authenticity is present as well, as Hussain considers the "filthy" part of Johannesburg to be the "real downtown" which could indicate that his experience of the inner city was thus far of a "filthy" environment. This makes reference to areas of the inner city, 
such as the Bree Taxi Rank, which have not been privately developed, unlike Marshalltown, and thus remain the material manifestations of urban decay which has been the signifier of the inner city for the last three decades (Beavon 2004).

John Dewar, owner of the Johannesburg Land Company responsible for multiple developments in the Marshalltown neighbourhood including the Main Street Mall, also relies on a discourse of cleanliness when explaining his manifesto for urban redevelopment:

Well first of all, any area that you go into, anywhere in the world, you've got to feel safe. So we've got very good security. 24 hours a day, seven days a week. Trained security guards who patrol. The second thing is it's got to be clean, so we make sure it's clean. Thirdly it's got to be attractive . People got to come and say "ah this is nice, let's sit here...". Those are the components for the possibility to feel safe, happy to be there, it's got to be attractive, you must be able to relax, and you must be able to get there.

Here, "clean" is put in relation with making the environment "attractive". Once again, there is a correlation between how the developer conceptualized the development on an urban environment - through a discourse of safety, cleanliness and attractiveness - and how it was experienced by a social actor who immediately noticed the cleanliness which took part in his construction of the space as attractive.

This visual proximity to global Western metropolises is what makes Marshalltown attractive to younger urban dwellers wanting to live the urban experience. In Andile Cele and Hussain van Roos's narratives, it is the fact that Marshalltown looks like New York or London, meaning a safe and clean area with signs of wealth and development, which makes it attractive. The discourse of safety present in John Dewar's manifesto will now be examined in the following section, particularly how the urban design for a safe neighbourhood is experienced in the semiotic landscape (Jaworski and Thurlow 2010) of the inner city by social actors and represented by the media.

\section{Urban development - a signifier of safety}

The Inner City of Johannesburg has suffered from its negative image when it comes to visitors avoiding it. A striking example of the fear of visiting Johannesburg's inner city can also be found in an online article from the BBC news website from $2002^{6}$, which on the basis of crime statistics calls South Africa (as a whole) "the most dangerous country in the world, which is not at war". The BBC asked its readers if they had been victim of crime in South Africa and if they answered in the affirmative, asked if they would share their stories. The article includes fifty-three stories from South Africans or visitors who had been to the country and had since then moved away, or not been back. They described how they had themselves been victims of carjackings, muggings, armed robbery, or had witnessed crimes, and how their relatives and friends had been victims of, or witnesses to, crime in South Africa. Johannesburg is mentioned thirteen times while Cape 
Town and Durban appear only five and four times respectively. One commenter trying to remain optimistic about South Africa still paints a disturbing picture of Johannesburg as a place to avoid as a whole:

I have just spent 2 months there. Seems to me a distinction can be made between Joburg \& the rest. In Joburg even the taxi drivers wouldn't take me near the city centre. The well off whites stay in heavily armed fortresses of shopping mall suburbia, whilst the blacks occupy the inner city and townships. This is no way to live. SA is bound to have a difficult time ahead to reverse the impact of decades of apartheid. I hope it can achieve this peacefully. I would add that I had a safe trip, and would go back - avoiding Joburg of course.

Even though the author mentions the city centre as the worst place to be since even taxi drivers won't take them there, giving credit to local knowledge, they conclude that "Joburg" (a common abbreviation of Johannesburg) as a whole should be avoided, to focus more on "the rest".

However, as we saw in the previous section, the neighbourhood of Marshalltown - located in the inner city - distinguishes itself very clearly from other areas of the inner city which have been associated with violence, insecurity, decay and crime since the mid-1980s (Beavon 2004; Baro forthcoming). Marshalltown is known both as the 'banking district' and as the 'mining district' because of the many mining and banking headquarters having historically been established there. Their presence has associated Marshalltown with wealth, while the rest of the inner city experienced capital flight, which saw buildings go uncared for by missing owners and banks redlining the areas for fear of not having loans repaid. Early private urban development efforts led by Marshalltown's wealthy corporate and private residents have made the area distinguish itself from the rest of the inner city known for its urban decay and crime statistics. The privatization of some parts of Marshalltown by these developers has allowed them to regulate urban life, indexing a feeling of safety through CCTV cameras and patrolling security guards.

Most of the people I interviewed talked about being pleasantly surprised when coming to Marshalltown for the first time, or returning there after many years of avoiding it, and realizing that it "wasn't bad at all". This attitude was exemplified by urban developer John Dewar of the Johannesburg Land Company when recollecting his first time back in the inner city when looking for empty buildings to buy and later redevelop:

So I went along with my then partner and we walked down Loveday Street, from City Hall to Main Street; we had our hands in our pockets and thinking we were going to be beaten on the head any minute, and suddenly realised it wasn't bad at all. So we then started looking at buildings and what would be available.

John Dewar's revelation happened in the early 2000s, but it seems that general negative perceptions persisted at least for the remainder of the decade.

In an interview with Thomas Coggin, the editor of the popular blog Urban Joburg, I asked him about his relationship with the inner city. He pointed out that he used to counter the narrative of Johannesburg being a no-go area by taking friends and relatives to see 
"the nice parts" of the city in the mid2000s. This would usually include a walk through "the Financial District" (another term for Marshalltown). At that time, he saw the area as containing the "original" beauty of Johannesburg because of its heritage buildings, but also because it was a diverse, multiracial place with white (collar) and black workers alike walking the streets and having lunch on the benches. Today, however, his experience of the beauty of Johannesburg is significantly wider; he tends to see the Financial District negatively as a place controlled by "corporate commercial interest" which makes it a nice-looking area but "not really diverse compared to other parts of the city". In terms of interactions, racial identities seemed to play a role, because Marshalltown is seen as more diverse, meaning that there are white people there too, unlike the rest of the inner city where being white is being part of a very small minority. Thomas elaborates, rather uncomfortably:

I felt safe there as this white upperclass student I suppose. If you were to go into other parts of the city you do end up being a minority so you sort of have to dive right in. I know how fucked up that sounds but you do have to dive right in and once you do you get less nervous, you realise it's the city, it's normal. You do have to have this introduction, so to speak. And that's where the financial district is helpful.

In his explanation, it is interesting how the experience of being a minority in public spaces is something new and required getting used to, as white people in South Africa are by far a minority with around $8 \%$ of the population, compared to Black people, who make up $80 \%$ of the population. So for a well-off white individual such as Thomas, a safe social action is perceived as involving a group of social actors where you don't feel like a minority. Being a minority is thus an important part of Thomas' structure of social interaction used to produce his discourse of Marshalltown (Scollon and Scollon 2003: 35). Indeed, his actions in Marshalltown are in direct interaction with the fact that he is a part of a racial minority. This narrative of social interactions links up with Murray (2011), who argues that the rise of gated communities and restricted areas in the suburbs of Johannesburg allows white citizens to avoid having to live the reality of being a minority in South Africa, because their neighbours or fellow shoppers in malls are mostly white, and also well-off.

Later in my interview with Thomas, I tried to grasp his vision of Marshalltown and what made it attractive, safe and worthy of visiting in terms of visual and place semiotics. His response was that first of all, "it was clean", which is opposed to being dirty, a term usually kept for describing the rest of the inner city. His other answers include the flowers, the security guards in neat uniforms, a sense of order such as a pedestrianized street, statues and signboards, and signage, such as for Anglo American: "You think, if Anglo American is here, then I as a white male can be here". It seems the sense of order is signifying of someone being in charge, and this 'someone' is later mentioned as being Anglo American. He later argues that these signs were put there for the white or upper-class employees of all these companies, to make them feel safe, and since he could get a job there, then he feels safe too and not out of place.

Coggin's decision to go into the inner city to experience urban life is facilitated by what he sees as signs of safety and 
control. Today, people sometimes visit the inner city of Johannesburg after seeing positive representations of the area in the media, as well as hearing mentions of places such as retail spaces or restaurant and activities offered which are deemed attractive. In 2013, the publication City Buzz emerged as a way to show the inner city in a good light, with articles on its quirky places such as the Ethiopian quarter, the Main Street Mall or the Kerk Street Market. The goal of this publication was to improve the image of the inner city by highlighting the types of urban lifestyles available, or the kinds of products one could consume there. I will expand on the role of the media in representing the Johannesburg inner city below.

After the flight of (mostly white) capital and residents throughout the 1980s and 1990s, in 1998 the Johannesburg Stock Exchange relocated from Diagonal Street in Marshalltown to the rapidly growing municipality of Sandton, today proudly claiming to be the "richest square mile in Africa" (as proclaimed on the webpage of the shopping mall Sandton City). What resulted over the years was the emergence of a dichotomy between the allegedly unsafe, unclean inner city, and the supposedly secure and controlled northern suburbs with a growing compoundization of suburban residences in Johannesburg (Murray 2011). This compoundization includes fences, walls, electric wires, sharp spikes, alarms, gates, burglar bars, and other architectural devices geared to keep unwanted bodies out of public spaces. In an op-ed published on the South African online news media outlet The Daily Maverick, Johannesburg is described as "unquestionably one of the most unequal and divided societies in the world, not just economically but spatially and socially". The author goes on to state that "there are very few points at which the lives of the poor and those in the middle classes intersect". The discourse of fear and violence attached to crime statistics helps to explain these deep divisions in Johannesburg, as the wealthy spatially separate themselves from the poor, and the local government treats the rare points of engagements such as street corner intersections as security risks in need of strict control. Indeed, it is common in Johannesburg to see poor people trying to make a living at busy intersections by selling cheap items like sunglasses or power cables for mobile phones as well as services such as windscreen cleaning or rubbish collection. The Daily Maverick op-ed condemns the fact that "the City is attempting to blame [crime at these spaces] on all people who try to make a living at these spaces, rather than on a small criminal minority".

Since the 2000s, the path towards the image change of South African cities from a violent one to a touristfriendly one has only widened, especially for Johannesburg, as travel guides and articles in mainstream Western publication praise the "rejuvenation" of the city and urge readers to go see it for themselves. The 2015 Rough Guides article on Johannesburg referenced in the introduction also describes the inner city as "explorable" although potential visitors should "remain alert". Another case of the slow progress made towards an image change for the inner city of Johannesburg is a 2013 Wall Street Journal article which documents young

7. http://www.wsj.com/articles/SB10001424127887324823804579016992423069988 
investors bringing capital back into the inner city, but still calling the moves a "high-wire act"7. Finally, a GQ article from 2015 urges the publication's readers to "get [themselves] to Johannesburg: the new cool capital of the southern hemisphere", comparing its appeal to Buenos Aires, Rio de Janeiro, Sydney and national rival Cape Town. The piece mentions walking tours of the inner city as a "must" in order to witness "the city's once stunning architecture being restored to its former glory" The author explains that improvements in the city are the result of investments over the last five years, which coincide with the FIFA World Cup as the moment Johannesburg's image problem began to change.

It thus seems that the discourse of safety is so crucial to urban development efforts in the inner city of Johannesburg because of the city's reputation of being dangerous has trickled down from the planning of such "clusters" by private developers to being seen as what comes with development. Thus, the media make an area appealing and attractive.

\section{CONGLUSION}

In this article, I have presented some aspects of (private) urban development in the inner city of Johannesburg and how it is discursively represented by developers, social actors and in the media. Using Markus and Cameron's (2002) discourse analysis approach, I have analysed those discourses in order to make sense of the representational aspect of the built environment. The analysis has shown the emergence of discourses of Western aspiration as well as of cleanliness and safety. I have argued that although Johannesburg's inner city has historically been conceptualised following architectural and urban trends from the West, contemporary urban development efforts have continued such pattern by implementing concepts like CIDs because they had worked in the West and because Johannesburg seemed to have followed logics of decay and regeneration also found in the West. Such aspirations are also felt in the language used by social actors in describing their experience of the privately developed clusters of the inner city.

I have also argued that cleanliness and safety have been at the forefront of changes in the perception of the inner city in order to change its negative image with a goal of attracting visitors. The language used by developers in their plans to make the city safe and clean can be found in media articles painting the inner city as having changed where pockets of development signify that it is safe to go there. Finally, social actors have also read such developments as the presence of CCTV cameras, security guards, white pedestrians and major corporation headquarters in the neighbourhood of Marshalltown as signs of safety allowing them to be there.

Markus and Cameron's (2002) language of buildings approach broadened to the field of urban design can be very useful in understanding the discursive process of conceptualising and building a place, which then helps us understand how this place comes to be represented by the media and experienced by social actors. Indeed, Johannesburg was tipped as cool in 2015 by Rough Guides not only because it was published in a major publication, but because developers used a particular global language of

8. http://www.gq-magazine.co.uk/article/best-things-to-do-in-johannesburg-south-africa 
contemporary urban development also found in the West which equates private, safe and clean spaces with hipness and a need to explore.

\section{REFERENGES}

Baro, Gilles. Forthcoming. The semiotics of heritage and regeneration: Postapartheid urban development in Johannesburg. In Tufi, Stefania and Malinowski, David (eds).

Questioning Boundaries, Opening Spaces: Reterritorialising Linguistic Landscapes.

Beavon, Keith Sidney Orrock. 2004. Johannesburg: The Making and Shaping of the City. University of South Africa Press.

Comaroff, Jean and Comaroff, John L. 2012. Theory from the South: Or, how Euro-America is evolving toward Africa. Boulder, CO: Paradigm Press.

Forty, Adrian. 2000. Words and buildings: a vocabulary of modern architecture (Vol. 268). London: Thames \& Hudson.

Iqani, Mehita and Baro, Gilles. 2017. The branded skyline? A socio-semiotic critique of Johannesburg's architectural adverts. African Studies 76(1): 1-19.
Jaworski, Adam and Thurlow, Crispin (eds). 2010. Semiotic Landscapes: Language, Image, Space. London: Continuum.

Markus, Thomas A. and Cameron, Deborah. 2002. The Words Between the Spaces: Buildings and Language. Psychology Press.

Milani, Tommaso. 2014. Marginally Speaking. Multilingual Margins 1(1): 9-20.

Murray, Martin J. 2011. City of extremes: the spatial politics of Johannesburg. Durham: Duke University Press.

Nuttall, Sarah and Mbembe, Joseph-Achille. 2008. Johannesburg: the elusive metropolis. Durham: Duke University Press.

Rajak, Dinah. 2011. In Good Company: An Anatomy of Corporate Social Responsibility. Stanford University Press.

Scollon, Ron and Scollon, Suzie Wong. 2003. Discourses in Place. London: Routledge.

Simone, AbdouMaliq. 2008. People as infrastructure. In Nuttall, Sarah and Mbembe, Joseph-Achille (eds). Johannesburg: The Elusive Metropolis. Duke University Press.

Simone, AbdouMaliq. 2010. City Life from Jakarta to Dakar: Movements at the Crossroads. Routledge. 